\title{
A Protein-Based Ferritin Bio-Nanobattery
}

\author{
Gerald D. Watt, ${ }^{1}$ Jae-Woo Kim, ${ }^{2}$ Bo Zhang, ${ }^{3}$ Timothy Miller, ${ }^{4}$ John N. Harb, ${ }^{4}$ \\ Robert C. Davis, ${ }^{5}$ and Sang H. Choi ${ }^{2,6}$
}

${ }^{1}$ Department of Chemistry and Biochemistry, Brigham Young University, Provo, UT 84602, USA

${ }^{2}$ Advanced Materials and Processing Branch, NASA Langley Research Center, Hampton, Virginia 23666, USA

${ }^{3}$ Industrial Bioscience Department, Genencor, Shanghai, China

${ }^{4}$ Department of Chemical Engineering, Brigham Young University, Provo, UT 84602, USA

${ }^{5}$ Department of Physics and Astronomy, Brigham Young University, Provo, UT 84602, USA

${ }^{6}$ National Institute of Aerospace, Hampton, VA 23666, USA

Correspondence should be addressed to Gerald D. Watt, gdwatt@chem.byu.edu

Received 26 January 2012; Accepted 20 March 2012

Academic Editor: A. M. Rao

Copyright (C) 2012 Gerald D. Watt et al. This is an open access article distributed under the Creative Commons Attribution License, which permits unrestricted use, distribution, and reproduction in any medium, provided the original work is properly cited.

\begin{abstract}
Nanostructured materials are increasingly important for the construction of electrochemical energy storage devices that will meet the needs of portable nanodevices. Here we describe the development of a nanoenergy storage system based on inorganic mineral phases contained in ferritin proteins. The electrochemical cell consists of an anode containing $\sim 2000$ iron atoms as $\mathrm{Fe}(\mathrm{OH})_{2}$ in the hollow protein interior of ferritin and a cathode containing $\sim 2000$ of $\mathrm{Co}(\mathrm{OH})_{3}$ in a separate ferritin molecule. The achieved initial voltage output from a combination of $\mathrm{Fe}^{2+}$ - and $\mathrm{Co}^{3+}$-ferritins adsorbed on gold electrodes was $\sim 500 \mathrm{mV}$, while a combination of $\mathrm{Fe}^{2+}$ - and $\mathrm{Co}^{3+}$-ferritins immobilized on gold produced a voltage of 350-405 mV. When fully discharged, $\mathrm{Fe}(\mathrm{OH})_{3}$ and $\mathrm{Co}(\mathrm{OH})_{2}$ are the products of a single electron transfer per metal atom from anode to cathode. The spent components can be regenerated by chemical or electrochemical methods restoring battery function. The properties of ferritins are presented and their unique characteristics are described, which have led to the development of a functional bio-nanobattery.
\end{abstract}

\section{Introduction}

Miniaturization of electronic devices has been a recent trend in high technology and continues to develop rapidly by enhancing efficiency, reducing power consumption, and increasing performance, speed, and functionality [1-4]. The development of nanoscale devices has notably accelerated, specifically for biomedical applications [5, 6]. Although such devices are near reality, the development of accompanying nanoscale energy storage technology has lagged, slowing their use and benefit. The exploitation of nanodevices will depend on the development of a reliable and mobile power supply to operate them. Currently, the power systems for nanoapplications are many times larger in size than the functional devices themselves. The development of nanoenergy storage systems is needed to eliminate large power supplies and enhance the benefits accrued by miniaturizing device size.
An important feature is to embed or integrate energy storage units with their accompanying nano devices, especially when it comes to autonomous systems. In addition, biocompatibility is a desirable feature to build into emerging nano-medical devices. Various inorganic metal components are currently used in many battery applications, and this same strategy appears to be a good approach for electrical energy storage on the nanoscale. If these metallic components are easily incorporated into biocompatible biological molecules by employing bioinorganic chemistry techniques, a basic energy storage unit can be formed at the nanoscale. We describe results that have led to the development of a nano-bioenergy storage system based on ferritin bioinorganic proteins [7] that have a number of desirable features, such as a nanoscale unit size, high-power production per unit size, thin-film fabrication capabilities, potential integration with energy harvesting units, and biocompatibility. 
1.1. General Background of Ferritin Properties. Ferritins are iron storage proteins widely distributed in nature that are involved in biological iron metabolism [8-10]. Heavily loaded ferritins contain $2000-4000 \mathrm{Fe}^{3+}$ atoms as $\mathrm{Fe}(\mathrm{OH})_{3}$ within their hollow interiors. When all iron has been removed from the protein shell it is called apoferritin; when filled with the $\mathrm{Fe}(\mathrm{OH})_{3}$ mineral, it is called holoferritin.

The ferritin structure is a segmented 24-subunit, hollow protein shell with an outer diameter of $12 \mathrm{~nm}$ and a hollow spherical cavity $8 \mathrm{~nm}$ in diameter with an $\mathrm{Mr}$ of $430 \mathrm{kDa}$. Two types of channels $(\sim 0.4 \mathrm{~nm}$ in diameter) at 3 - and 4 fold protein axes penetrate the $2.0 \mathrm{~nm}$ shell and connect the interior cavity with the external solution. In its biological role as an iron storage protein, the surrounding protein shell protects the iron mineral core from reaction with the exterior solution and the channels function as pores through this "membrane shell" and serve the unique role of ion transport. Large or negatively charged species are excluded, but small ions and molecules readily enter and leave the ferritin interior through these channels $[11,12]$. The assembled structure of ferritins is remarkably stable to biological extremes of temperature $\left(80^{\circ} \mathrm{C}\right)$ and $\mathrm{pH}(2.0-10.0)$.

\section{Results}

2.1. Fundamentals of Battery Operation. Construction and operation of a typical battery consist of four basic concepts. First, two electrically isolated electrochemically active components that have different redox potentials are required, so there is a favorable thermodynamic driving force $\left(\Delta G^{\circ}\right.$ is negative) for electrons to transfer from the electron-rich to the electron-deficient mineral phase. If internal resistance is ignored, the difference in redox potential of these two phases determines the battery operating potential.

Second, current collecting electrodes must make electrical contact with each phase to electrically link the two isolated battery compartments and provide an external electrical pathway for electron flow. These two electrodes are the anode $(-$, in contact with the electron rich phase) and the cathode $(+$, in contact with the electron deficient phase).

Third, an ion-permeable barrier must separate and electrically isolate the two battery components. This membrane permits ion transfer between the individual battery compartments that must occur during the charging and discharging cycles as a result of the current generating chemical reactions, while electrically isolating the electrodes to prevent internal discharge. Physical separation (no membrane) of the electrodes may be sufficient if the active materials are firmly attached to the current collectors and are not mobile in solution.

The fourth requirement for efficient power storage (coulombs/gram) is to maximize the number of electrons that are transferred to and from the metal centers of the battery components.

We first present the concept of a nanobattery using ferritins with different core minerals and then describe the construction and electrochemical testing of a functional cell. The unique characteristics possessed by ferritins allowing formation of a ferritin-based battery are presented later.

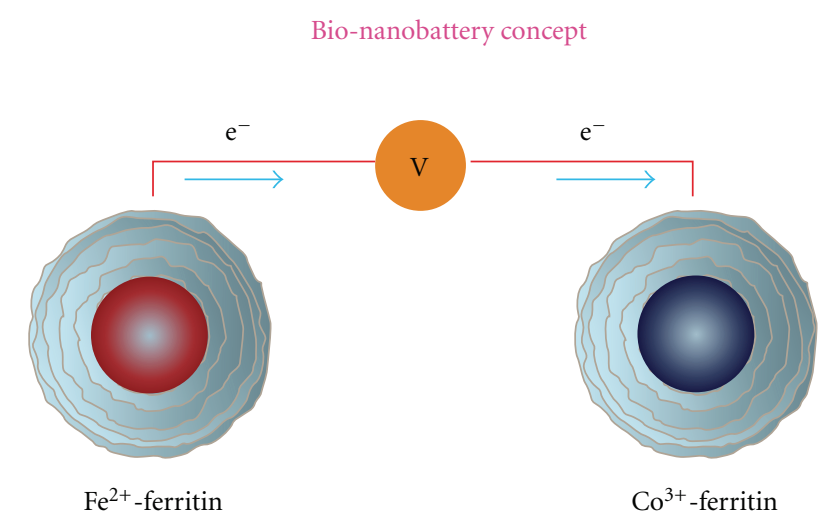

FIGURE 1: Schematic view of a bio-nanobattery formed from ferritin containing a $\mathrm{Fe}(\mathrm{OH})_{2}$ mineral core connected to a ferritin containing a $\mathrm{Co}(\mathrm{OH})_{3}$ mineral core. The cutout view shows the mineral cores within each ferritin type. The ferritin battery components are immersed in buffer, which is typically $0.05 \mathrm{M} \mathrm{pH}$ 7.0-9.0 containing $0.10 \mathrm{M} \mathrm{NaCl}$.

2.2. Bio-Nanobattery Construction and Testing. Figure 1 shows that two individual ferritin types, $\mathrm{Fe}(\mathrm{OH})_{2}$ and $\mathrm{Co}(\mathrm{OH})_{3}$, form the two components of the bio-nanobattery and meet the four criteria outlined above for battery operation. Each ferritin type is in contact with a buffered solution, and the individual gold electrodes are separated by an ion-permeable membrane. When the circuit is closed, electrons flow through the external circuit from the anode to the cathode. During cell discharge, reaction (1) yields one electron and takes up one $\mathrm{OH}^{-}$and reaction (2) requires one electron and produces one $\mathrm{OH}^{-}$, giving the overall $\mathrm{pH}$ neutral reaction $(3)$.

When $\mathrm{Fe}(\mathrm{OH})_{2}$-containing ferritin is combined with ferritin containing the $\mathrm{Co}(\mathrm{OH})_{3}$ half cell, a stable opencircuit potential of $\sim 500 \mathrm{mv}$ at $\mathrm{pH} 9.0$ was measured, consistent with the redox potentials in Table 1. Figure 2 shows performance characteristics during the initial discharge cycle of this ferritin $\mathrm{Fe}(\mathrm{OH})_{2} / \mathrm{Co}(\mathrm{OH})_{3}$ bio-nanobattery as summarized by reactions (1)-(3). When discharged at closed circuit at 100 namps (Figure 2), all electrons were transferred from $\mathrm{Fe}(\mathrm{OH})_{2}$ to $\mathrm{Co}(\mathrm{OH})_{3}$ according to reaction (3):

$$
\begin{gathered}
\mathrm{Fe}(\mathrm{OH})_{2}+\mathrm{OH}^{-}=\mathrm{Fe}(\mathrm{OH})_{3}+\mathrm{e} \\
\mathrm{Co}(\mathrm{OH})_{3}+\mathrm{e}=\mathrm{Co}(\mathrm{OH})_{2}+\mathrm{OH}^{-} \\
\mathrm{Fe}(\mathrm{OH})_{2}+\mathrm{Co}(\mathrm{OH})_{3}=\mathrm{Fe}(\mathrm{OH})_{3}+\mathrm{Co}(\mathrm{OH})_{2} .
\end{gathered}
$$

We have also constructed and tested a battery system using $\mathrm{Mn}(\mathrm{OH})_{3}$ in place of $\mathrm{Co}(\mathrm{OH})_{3}$ under the same conditions, which performs similar to that shown in Figure 2. Other results with both $\mathrm{Co}(\mathrm{OH})_{3}$ and $\mathrm{Mn}(\mathrm{OH})_{3}$ are considered next in a different application.

The cell just described is a "bulk" electrochemical cell because the ferritin concentrations exceed the amount of ferritin that can bind to the gold electrodes and demonstrates 
TABLE 1: Electrochemical properties of ferritins with different core minerals.

\begin{tabular}{llcc}
\hline Reaction & Ferritin Core & $\mathrm{mV}$ & $\mathrm{pH}$ \\
\hline $\mathrm{Fe}(\mathrm{OH})_{3}+\mathrm{e}=\mathrm{Fe}(\mathrm{OH})_{2}+\mathrm{OH}^{-}$ & Native HoSF & -190 to -420 & $7.0-9.0$ \\
$\mathrm{Co}(\mathrm{OH})_{3}+\mathrm{e}=\mathrm{Co}(\mathrm{OH})_{2}+\mathrm{OH}^{-}$ & Synthetic HoSF & +50 & 7.0 \\
$\mathrm{Mn}(\mathrm{OH})_{3}+\mathrm{e}=\mathrm{Mn}(\mathrm{OH})_{2}+\mathrm{OH}^{-}$ & Synthetic HoSF & +35 & 7.0 \\
$\mathrm{Fe}(\mathrm{OH})_{2}\left(\mathrm{PO}_{4}\right)+\mathrm{e}=\mathrm{Fe}(\mathrm{OH})\left(\mathrm{PO}_{4}\right)+\mathrm{OH}^{-}$ & Native bacterialc ferritin & -430 & $7.0-9.0$ \\
$\mathrm{Fe}(\mathrm{OH})_{2}\left(\mathrm{PO}_{4}\right)+\mathrm{e}=\mathrm{Fe}(\mathrm{OH})\left(\mathrm{PO}_{4}\right)+\mathrm{OH}^{-}$ & Synthetic HoSF & -300 & 7.0 \\
$\mathrm{Ni}(\mathrm{OH})_{3}+\mathrm{e}=\mathrm{Ni}(\mathrm{OH})_{2}+\mathrm{OH}^{-}$ & Synthetic HoSF & -1000 & 7.0 \\
\hline
\end{tabular}

${ }^{a}:$ [20]; b: [22]; c: [24].

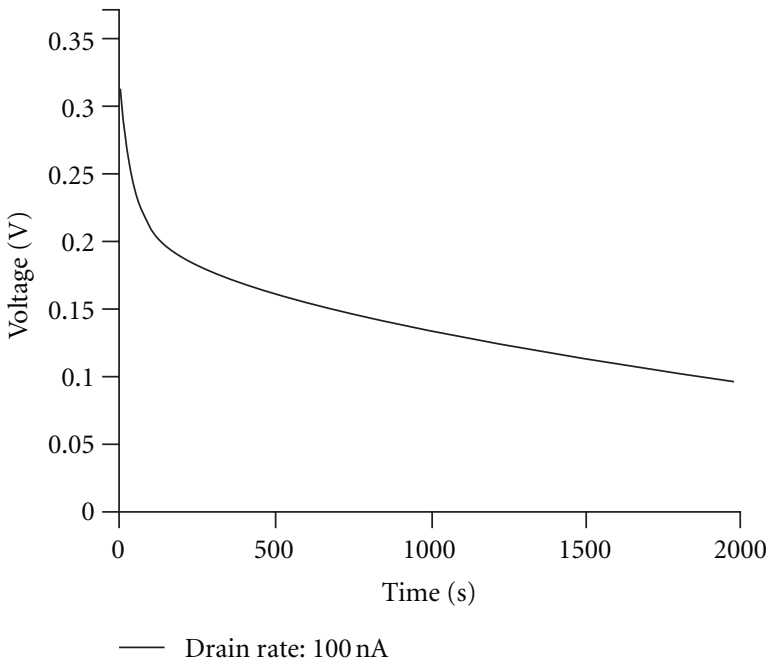

FIGURE 2: Voltage versus time discharge curve. A small, unstirred bulk electrochemical cell consisting of ferritin containing a $\mathrm{Fe}(\mathrm{OH})_{2}$ mineral core connected to a ferritin containing $\mathrm{Co}(\mathrm{OH})_{3}$ mineral core in $0.05 \mathrm{M}$ MOPS $\mathrm{pH} 8.0$ was discharged at a drain rate of $100 \mathrm{nA}$. Each ferritin contained 2000 metal ions per mineral core.

the feasibility of using ferritins as battery components. However, diffusion of ferritins to the current collecting electrodes in such a cell becomes a limiting factor in current flow. In an attempt to miniaturize the cell size to minimize diffusion and to eliminate excess ferritin beyond that which binds to the electrode, we investigated ferritin bound only to the electrode surface. With this approach, a nanobattery consisting of only surface-bound ferritin molecules can be constructed whose size and charge capacity are determined by the electrode surface coverage and the smallness of the gold line onto which the ferritins bind. During attempts to create such a small cell, different electrical properties were encountered than those observed for the bulk cell.

Contrary to previous reports [13-15], purified ferritin in the presence of a clean gold electrode did not demonstrate the ability to rapidly oxidize or reduce the mineral core during cyclic voltammetry, as shown as the left curve in Figure 3. Electrochemical reactivity of redox proteins can be augmented by addition of chemical promoters, which catalytically facilitate electrochemical reactions [16]. Addition of thioglycolic acid (TGA) at $<0.01 \mathrm{mM}$ to a ferritin solution, while applying an adsorbing potential of $+500 \mathrm{mV}$ (SCE), caused ferritin to adsorb onto the gold electrode and exhibit electro activity shown by the right curve in Figure 3 .

Figure 4 shows AFM images of ferritin adsorbed at $+500 \mathrm{mV}$ both without (a) and with (b) the TGA promoter. Figure 5 shows the discharge characteristics of a $\mathrm{Mn}(\mathrm{OH})_{3} / \mathrm{Fe}(\mathrm{OH})_{2}$ cell composed only of surface adsorbed ferritins in the presence of TGA promoter, and the charge transferred during discharge was $90 \mu \mathrm{C}$. This corresponds to 500 electrons transferred per ferritin, which was equivalent to the concentrations of $\mathrm{Fe}^{2+}$ - and $\mathrm{Mn}^{3+}$-ferritins present in the bound ferritins. The smaller loading was used to demonstrate that all electrons were removed even from smaller cores.

Several different ferritin-binding configurations using two different ferritin types (Co and $\mathrm{Mn}$ ) bound to different electrodes were also investigated. Surface adsorbed ferritins containing $\mathrm{Fe}(\mathrm{OH})_{2}$ and $\mathrm{Co}(\mathrm{OH})_{3}$ or $\mathrm{Mn}(\mathrm{OH})_{3}$ on gold electrodes typically produced $>420 \mathrm{mV}$ open circuit.

The facile electrochemical reactions observed in the absence of promoter shown in Figure 2 for the bulk battery stands in contrast to the promoter-requiring behavior seen in Figure 5. This behavior may have an explanation resulting from the methods of preparation of apoferritins and to the relative amounts of each used in the respective experiments. Apoferritins are prepared by removal of the iron mineral cores with TGA [8-10] or sodium dithionite, both of which function as promoters. Although rigorous processing is typically carried out to remove these constituents, it is possible that very small amounts remain free or ferritin bound in the ferritin solution. The use of bulk quantities of ferritin in Figure 2 compared to surface quantities used in Figure 5 would provide for more promoters to be available in the bulk cell, causing it to function without added promoter (but to function by "adventitious promoters") compared to experiments with only surface bound ferritins. In any case, the results show that ferritins can function as electrochemical cell components (in bulk or surface-bound) in an electrochemical energy storage role.

To assure permanent attachment and to increase the surface coverage for greater charge capacity, ferritins were chemically attached to the gold surface. When subjected to negative voltage cycling in the presence of $\mathrm{Fe}^{2+}$ chelators, the $\mathrm{Fe}^{3+}$ in the chemically attached holoferritin was reduced 


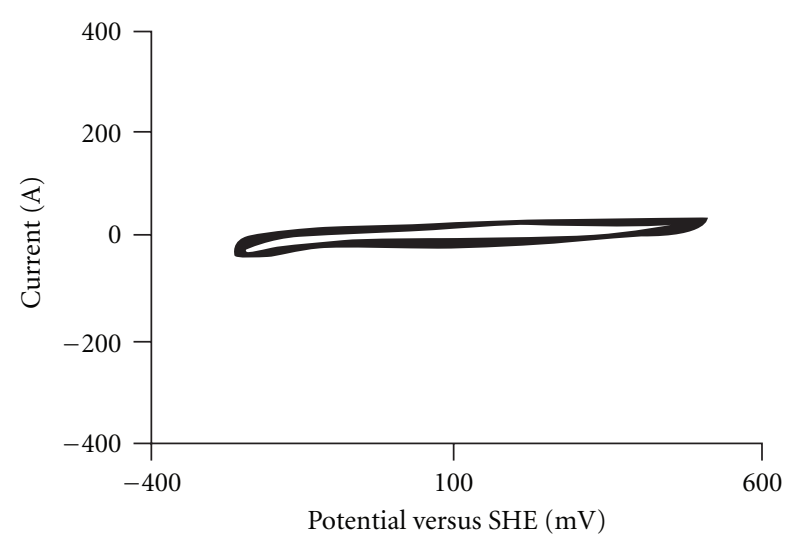

(a)

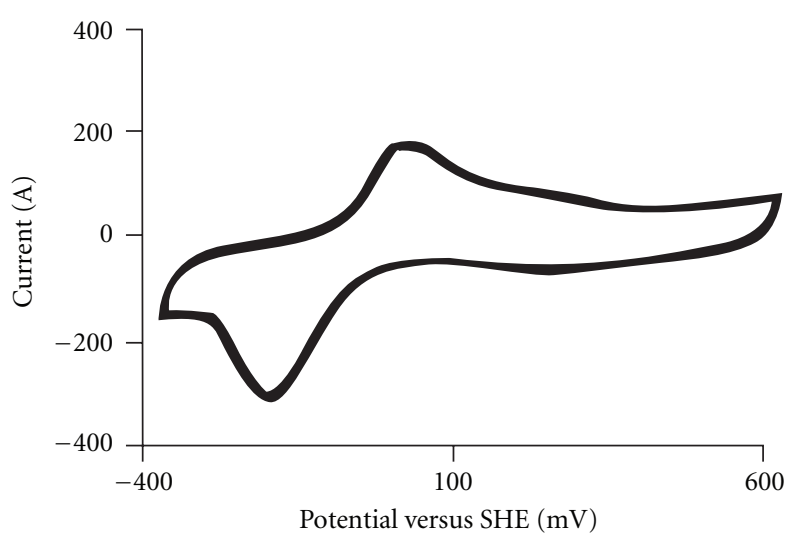

(b)

Figure 3: Cyclic voltammograms of ferritin on a $6 \mathrm{~cm}^{2}$ bare gold electrode. Ferritin equilibrated at zero potential or at $-200 \mathrm{mv}$, (a). Ferritin adsorbed at $+500 \mathrm{mv}$, (b). The voltage was cycled at $100 \mathrm{mV} / \mathrm{s}$ in $0.05 \mathrm{M} \mathrm{MOPS} \mathrm{pH} 7$ with $0.05 \mathrm{mM}$ TGA as promoter.

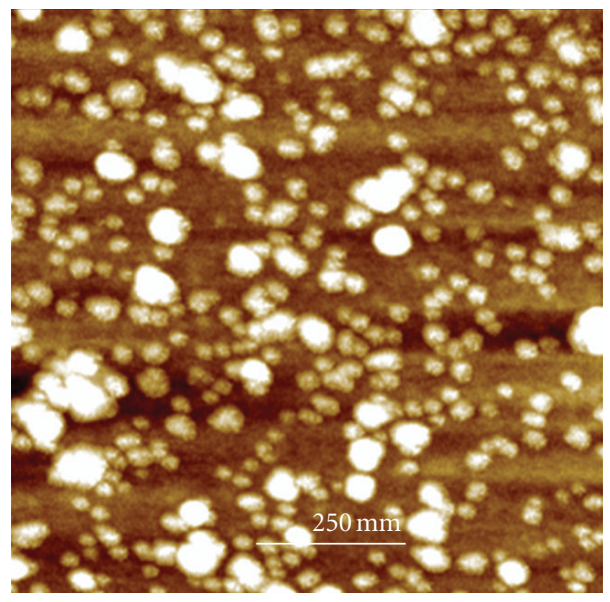

(a)

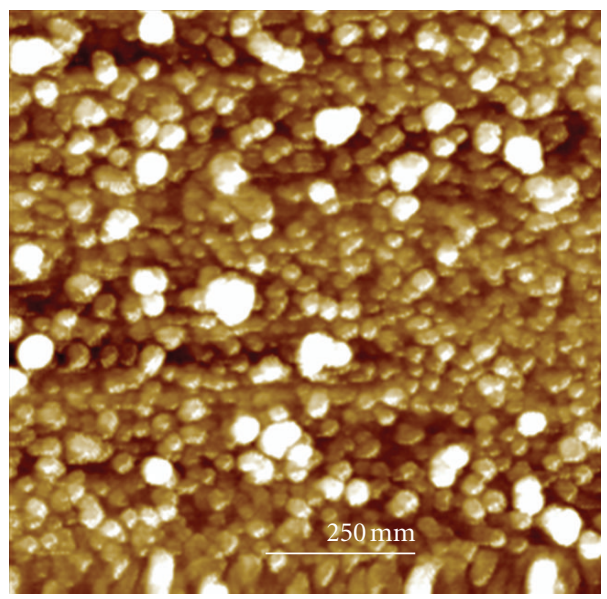

(b)

FIGURE 4: AFM images of (a) ferritin adsorbed without the TGA promoter (height scale $=30 \mathrm{~nm}$ ) and (b) ferritin adsorbed in the presence of $0.05 \mathrm{mM}$ TGA (height scale $=20 \mathrm{~nm}$ ). The TGA promoter results in greater, more uniform coverage of the surface with ferritin. Scale bar is $250 \mathrm{~nm}$ for both images.

and the resulting $\mathrm{Fe}^{2+}$ was immediately chelated forming apoferritin $[14,15]$. When this process was reversed in anaerobic buffer containing $\mathrm{Fe}^{2+}$ and cycled in the oxidizing direction, holoferritin was once again formed [14]. Both redox cycling experiments were performed in the absence of added promoters or mediators, demonstrating direct electron transfer from electrode to mineral core through the chemically bound protein shell. Both physical adsorption and chemical attachment of ferritin to gold electrodes led to electroactive ferritin layers, but chemical attachment was more stable. Chemical attachment produced slightly lower open-circuit voltages.

The results show that the minimum requirements for a ferritin-based nanobattery are the attachment of two different ferritin types to two different gold electrodes both in close proximity and in contact with a minimal volume of buffer necessary to support reactions (1)-(3) during cell function.
The size of the biobattery can be scaled to very small dimensions and is limited only by the size of an inscribed gold line onto which the ferritins are adsorbed or chemically tethered. If chemical attachment is used, no membrane is required as long as the electrodes are physically separated because the lack of mobility of the chemically bound ferritin precludes interaction. For physically adsorbed ferritin, a membrane is desired because internal cell discharge can occur if anodic and cathodic ferritins in close proximity exchange between solution and electrode [17].

The minimum battery unit consisting of one anodic and one cathodic ferritin molecule as shown in Figure 1 is $5 \times$ $10^{-16}$ coulombs for a theoretical loading of 3000 metal atoms per ferritin. The coulombic capacity of any ferritin-based battery can then be calculated by multiplying the ferritin surface coverage of the electrode by the charge of this basic battery unit. An upper limit of 200 coulombs/g can 


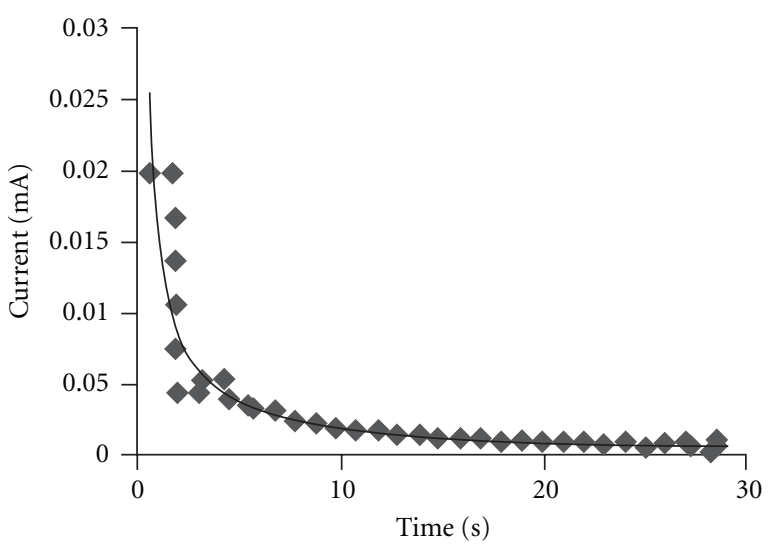

Figure 5: Discharge curve of a cell containing $500 \mathrm{Fe}(\mathrm{OH})_{2}$ and 500 $\mathrm{Mn}(\mathrm{OH})_{3}$ attached to gold electrodes by deposition at $+500 \mathrm{mV}$ in the presence of TGA. The solid line is an exponential fit to the data and was used to calculate that $90 \mu$ coulombs transferred through the cell.

be calculated (excluding buffer) using the fundamental components in Figure 1.

An ongoing approach for improving the coulombic capacity of a ferritin nanobattery is presented in Figure 6, which shows a native ferritin that is negatively charged due to its ionized surface carboxylate groups at $\mathrm{pH} 7-9$ first adsorbed or chemically tethered to an electrode surface.

Next, ferritin is "cationized" by having its surface carboxyl groups modified by attaching $-\mathrm{NH}_{3}{ }^{+}$groups. This cationized ferritin binds to the negatively charged "basement" ferritin layer attached to the electrode, forming a second, positively charged layer. By alternating ferritins of different charges, a layered electrode is formed. At this stage of development, five alternate layers have been formed as shown by the AFM and SEM images in Figure 6, demonstrating the feasibility of a multilayer nanobattery.

\section{Materials and Methods}

Both holo and apo horse spleen ferritin (HoSF) were obtained from Sigma and were further purified and characterized as previously reported $[13,18,19]$. Ferritin containing $\mathrm{Fe}(\mathrm{OH})_{2}$ mineral cores was prepared [20] either by reduction using carbon monoxide dehydrogenase $(\mathrm{CODH} / \mathrm{CO}$, reaction (4)) or $\mathrm{MVH}_{2}$ as summarized by the reaction sequences (4)-(5) and (6)-(7), respectively. $\mathrm{Co}(\mathrm{OH})_{3}$ and $\mathrm{Mn}(\mathrm{OH})_{3}$ were prepared as previously described [21]:

$$
\begin{gathered}
2 \mathrm{MV}+\mathrm{CO}+\mathrm{H}_{2} \mathrm{O}=2 \mathrm{MVr}+\mathrm{CO}_{2}+2 \mathrm{H}^{+}, \\
\mathrm{MVr}+\mathrm{Fe}(\mathrm{OH})_{3}=\mathrm{MV}+\mathrm{Fe}(\mathrm{OH})_{2}+\mathrm{OH}^{-}, \\
\mathrm{MV}+\mathrm{MVH}_{2}=2 \mathrm{MVr}+2 \mathrm{H}^{+}, \\
\mathrm{MVr}+\mathrm{Fe}(\mathrm{OH})_{3}=\mathrm{MV}+\mathrm{Fe}(\mathrm{OH})_{2}+\mathrm{OH}^{-} .
\end{gathered}
$$

Because ferritin with a $\mathrm{Fe}(\mathrm{OH})_{2}$ mineral core is highly susceptible to $\mathrm{O}_{2}$-oxidation, all preparation and handling procedures were conducted in vacuum atmospheres glove boxes with $\left(<1.0 \mathrm{ppm} \mathrm{O}_{2}\right)$.

Bulk cell measurements were conducted in a twochambered Lucite cell separated by a $10 \mathrm{KDa}$ cellulose membrane. One chamber contained $\sim 1.0 \mathrm{~mL}$ of an anaerobic $\mathrm{Fe}(\mathrm{OH})_{2}$-ferritin and the other a solution of $\mathrm{Co}(\mathrm{OH})_{3}$ or $\mathrm{Mn}(\mathrm{OH})_{3}$-ferritin in $0.05 \mathrm{M}$ Mops buffer $\mathrm{pH} 7.0-9.0$ containing $0.10 \mathrm{M} \mathrm{NaCl}$. The ferritins were at $5-20 \mathrm{mg} / \mathrm{mL}$ and contained 500-2000 metal atoms per ferritin core. Each chamber also contained a gold electrode, which was connected through an external circuit. For electrodes containing only surface-bound ferritins, the gold electrodes were first cleaned in Piranha solution, rinsed, and placed in the desired anaerobic ferritin solution containing $0.01-0.10 \mathrm{mM}$ thioglycolic acid (TGA). The electrodes were then equilibrated at $+500 \mathrm{mV}$ to adsorb the ferritins. Each electrode was rinsed anaerobically to remove unbound ferritins and free TGA. Electrical measurements were made using a EG\&G PAR 263A potentiostat/galvanostat controlled by Power Suites software.

\section{Discussion}

Having established that "bulk," "surface-adsorbed," and "chemically tethered" ferritin-containing electrodes are readily constructed and that their performance is consistent with known half-cell values in Table 1, we now discuss the unique ferritin characteristics that have led to the concept and eventual fabrication of a functional ferritin bio-nanobattery. These concepts form the basis for future development and improvement.

\subsection{Chemical Reconstitution of Ferritins for Cathode and Anode Materials}

4.1.1. Anode Materials. Viable candidates for bio-nanobattery anode materials are oxyhydroxides of light transition metals with low reduction potentials that are compatible with known ferritin properties. Iron was first considered, but the oxidation state of iron in isolated ferritin is $\mathrm{Fe}(\mathrm{OH})_{3}$ and does not yield electrons at low potential. However, the native $\mathrm{Fe}(\mathrm{OH})_{3}$ mineral core undergoes [20] a $\mathrm{pH}$-dependent reduction $(-120 \mathrm{mv} / \mathrm{pH}, \mathrm{pH}$ 7.0-9.0, Table 1) to form $\mathrm{Fe}(\mathrm{OH})_{2}$. The $\mathrm{Fe}(\mathrm{OH})_{2}$ mineral core is stable $[17,20,22]$ within the ferritin interior at $\mathrm{pH}>7.0$. The absence of $\mathrm{Fe}^{2+}$ chelators is critical to maintaining the $\mathrm{Fe}(\mathrm{OH})_{2}$ mineral core, and a number of methods to produce stable $\mathrm{Fe}(\mathrm{OH})_{2}$ have been explored $[20,22,23]$. The MV-mediated chemical procedures outlined in the Materials and Methods Section are convenient methods for core reduction. The $\mathrm{Fe}(\mathrm{OH})_{2}$ mineral core is readily oxidized to $\mathrm{Fe}(\mathrm{OH})_{3}$ with $\mathrm{O}_{2}$ and other oxidants $[10,18]$, demonstrating redox reversibility. For chemically attached ferritins, the mineral cores undergo direct electron transfer via electrochemical voltage cycling without need for chemical reduction (Figure 3). Ferritin with an $\mathrm{Fe}(\mathrm{OH})_{2}$ mineral core was used exclusively in the experiments described here because of its availability and convenience of formation, but other more strongly reducing mineral cores are desirable and are being evaluated. 
Protein bio-nanobattery

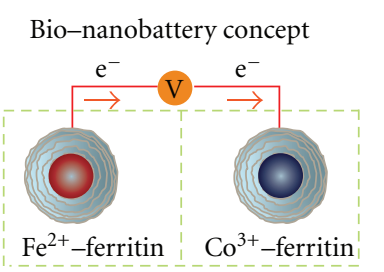

Electrode
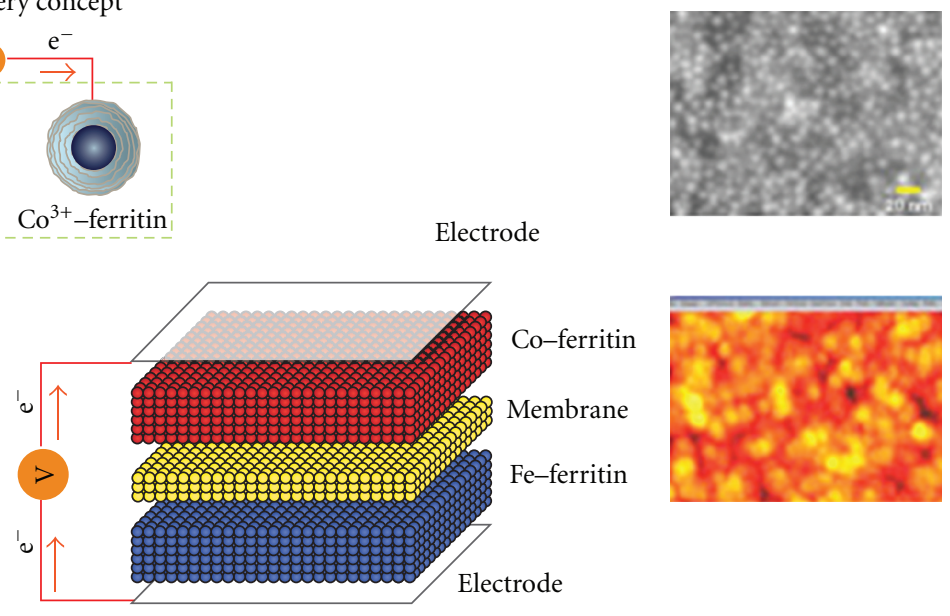

FIgure 6: A multilayered ferritin bio-nanobattery for high coulomb capacity, high efficiency, compact size, and flexible applications. The anodic and cathodic battery components are formed by alternating layers of oppositely charged ferritins. The blue is the anodic layer, and the red is the cathodic layer. The yellow membrane between the two layers is not needed if excess ferritins are not present. The image on the upper right is a SEM image of five layers of ferritin. The image on the lower right is an AFM image of five ferritin layers.

The phosphate-containing mineral core from Azotobacter vinelandii is readily reduced to $\mathrm{Fe}(\mathrm{II})$ and retained within the protein cavity $[19,23,24]$. This iron (II) core is more strongly reducing at $\mathrm{pH} 7.0$, but because it is not as readily available, its use as a bio-nanobattery anode has been limited. An important difference between animal and the phosphatecontaining bacterial ferritins is that animal ferritin has a $\mathrm{pH}$-dependent reduction potential whereas that for bacterial ferritin is $\mathrm{pH}$ independent $[19,20]$. Therefore, the voltage output from an electrochemical cell made from animal ferritin is tunable with $\mathrm{pH}$, whereas that for bacterial ferritin is not.

4.1.2. Cathodic Materials. The addition of $\mathrm{Fe}^{2+}$ to apoferritin using $\mathrm{O}_{2}$ or other oxidizing agents readily reconstitutes the native $\mathrm{Fe}(\mathrm{OH})_{3}$ mineral core to 500-3000 Fe/ferritin [8-10].

Reconstitution using variations of this site-specific biomineralization process produces ferritins with an impressive variety of interesting and possibly technologically useful, but nonnatural, nanomineral cores [25-28]. Of interest in creating a bio-nanobattery are ferritins containing the oxidizing $\mathrm{Co}(\mathrm{OH})_{3}$ and $\mathrm{Mn}(\mathrm{OH})_{3}$ mineral cores with 500-2000 metal atoms per ferritin $[21,29]$. Chemical and electrochemical characterization (Table 1) established that these mineral cores are reduced at potentials near $+50 \mathrm{mv}$ with retention of the $\mathrm{Co}(\mathrm{OH})_{2}$ and $\mathrm{Mn}(\mathrm{OH})_{2}$ minerals [22]. The stability of $\mathrm{M}(\mathrm{OH})_{2}\left(\mathrm{M}=\mathrm{Fe}, \mathrm{Co}, \mathrm{Mn}, \mathrm{Ksp}=\sim 10^{-16}\right)$ is quite remarkable and is likely due to both kinetic and thermodynamic effects. $\mathrm{M}^{2+}$ and $\mathrm{M}^{3+}$ bind strongly within the ferritin channels, and, once the $\mathrm{M}(\mathrm{OH})_{2}$ core is formed, transfer of $\mathrm{M}(\mathrm{OH})_{2}$ to the external solution is blocked [10] by channelbound $\mathrm{M}^{2+}$.

$\mathrm{Co}(\mathrm{III})$ and $\mathrm{Mn}(\mathrm{III})$ ferritins when combined with $\mathrm{Fe}(\mathrm{OH})_{2}$ successfully functions as cathodic components producing a bulk cell potential of $\sim 500 \mathrm{mV}$. Higher cell potentials are desired and can be achieved in two ways. The anode material could be more strongly reducing, or the cathodic component could be more strongly oxidizing or a combination of both. The use of $\mathrm{Ni}(\mathrm{OH})_{3}$ as cathodic material could produce a predicted cell potential near 1.0 volt. Our best results give a mixed mineral core with $\sim 50 \%$ $\mathrm{Ni}(\mathrm{OH})_{3}$ and $\mathrm{Ni}(\mathrm{OH})_{2}$, and with this mixture a higher cell voltage is produced as predicted but a well-defined system remains elusive.

4.2. Current Collecting Electrodes. Intimate contact of anodic and cathodic cell components with electrodes is essential for efficient electron transfer and also for lowering internal cell resistance. The contact of ferritin with the electrode and requisite electron transfer from the core material through the protein shell initially seemed to be serious limitations in battery operation. However, two unique properties of the ferritin protein shell eliminate these restrictions and allow for specific interaction with electrodes.

Previous studies have shown [17] that rapid electron transfer occurs through the HoSF shell. To explain this apparent anomalous behavior, an endogenous electron transfer pathway was postulated [30], consisting of a protein redox center involving tryptophan 91 . This electron transfer characteristic of the ferritin protein shell was demonstrated when $\mathrm{Fe}(\mathrm{II})$-ferritin was reacted with $\mathrm{Co}(\mathrm{III})$-ferritin, both free in solution, and within seconds $\mathrm{Fe}(\mathrm{III})$-ferritin and $\mathrm{Co}(\mathrm{II})$-ferritin were formed by electron transfer through the two intervening protein shells [17]. Even faster electron transfer was observed with bacterial ferritins, presumably through the 12 protoporphyrin IX groups. Electron transfer was further enhanced [17] by addition of a small piece of metallic gold. This enhancement occurred by $\mathrm{Fe}(\mathrm{OH})_{2}$ and $\mathrm{Co}(\mathrm{OH})_{3}$ ferritins binding to and exchanging electrons through the same gold conductor instead of randomly 


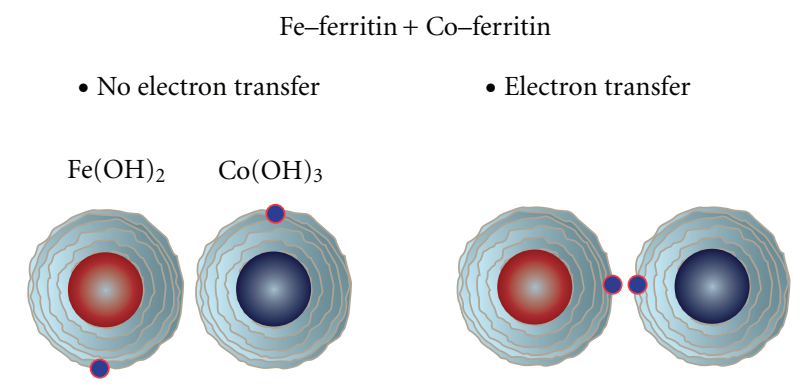

FIGURE 7: Electron transfer through the ferritin protein shell. The blue dot in the cut-away view of the protein shells containing $\mathrm{Fe}(\mathrm{OH})_{2}$ (pink) and $\mathrm{Co}(\mathrm{OH})_{3}$ (purple) mineral cores represents the electron transfer centers within the ferritin shell. The model on the left indicates that the two electron transfer centers are not in contact and do not provide a pathway for electron exchange. The model on the right shows the two redox centers aligned and capable of exchanging electrons from the two mineral cores. The models only show one of several possible electron transfer centers present in each ferritin protein shell.

contacting each other in solution, as suggested by Figure 7 . The protein shells thus protect the mineral cores from contact with bulk solution while simultaneously providing electron transfer capability through the protein shell.

4.2.1. Physiochemical Adsorption. Binding of ferritins to metallic and nonmetallic surfaces has been extensively studied [31-34]. The adsorption process is essential in creating a high-density surface layer, which provides for high current density on the current collecting electrodes. Each ferritin subunit possess a cysteine at position 90, and when assembled into the 24-mer, one cysteine from each of three subunits is positioned at the corners of a triangle at the outside entrance of each of the eight 3-fold channels. As there are eight threefold channels per symmetrical ferritin molecule, all ferritin molecules are strongly bound and attached identically to the electrode surface. Binding at the 3-fold channel also properly orients the ferritinelectrode interaction to maximize electron transfer through the proposed electron transfer pathway through the protein shell [17]. However, in spite of this natural binding affinity, it seems that promoters are also required to facilitate electron transfer.

4.2.2. Chemical Attachment. Chemical immobilization of ferritin on gold electrodes is achieved through two different procedures $[35,36]$. The first directly attaches a terminal thiol group to the ferritin exterior via reaction with thiol-containing organic molecules followed by attaching the thiolate group on the gold electrode. The second method requires modification of the $\mathrm{Au}$ electrode with thiol-derivatized molecules such as dithiobis- $\mathrm{N}$-succinimidyl propionate (DTSP) and then reaction of the amino surface groups of ferritin with the thiol-derivatized gold surface. Using these methods, highly concentrated and electroactive ferritin layers are obtained [14].
4.2.3. Electrical Conductivity of the Core Materials. In addition to the observed electron transfer through the protein shell, it is also essential that the mineral core be sufficiently conducting that all electrons flow from the mineral through the protein shell and then to the electrode. Core conductivity of the ferritin mineral was established $[37,38]$ when ${ }^{57} \mathrm{Fe}^{2+}$ was added anaerobically to $\mathrm{Fe}(\mathrm{III})$-containing native mineral cores, and ${ }^{57} \mathrm{Fe}^{3+}$ was observed by Mossbauer spectroscopy. This result showed that electrons were transferred from the entering ${ }^{57} \mathrm{Fe}^{2+}$ to and delocalized into the bulk $\mathrm{Fe}(\mathrm{OH})_{3}$ mineral core, implying mineral conductivity. A definitive demonstration of the conductivity of both the mineral core and the protein shell was established by placing a conductive atomic force microscope tip on single molecules of holo- and apoferritin and showing that the conductivity of holoferritin was 3-4 times greater than the apo counterpart [39].

4.3. The Ferritin Shell Is an Ion Permeable Membrane: The Ferritin Channels. X-ray crystallography [40, 41] of apo ferritin shows the presence of channels at three- and fourfold axes (0.3-0.4 $\mathrm{nm}$ in diameter) where three and four subunits intersect. The hydrophylic 3 -fold channels are used for ion transfer into and out of the ferritin but the role of the hydrophobic 4 -fold channels remain unclear. However, that ions and molecules enter and leave through these channels is well documented [12].

Trapping large organic dye molecules and ferricyanide in the ferritin interior established [11] that their large size precluded their release. Studies [12] with nitroxide molecules confirmed this view by demonstrating that they only slowly exchanged (hours) with the ferritin interior. Recently, it was shown that $\mathrm{Fe}^{2+}$ and $\mathrm{Fe}^{3+}$ rapidly enter into the ferritin interior through the channels [42]. Other studies suggest [43] that the channel openings are fluxional and may actually change dimensions under certain conditions, which facilitates ion transfer. Such studies establish that the channels make effective transport pathways for ions and small molecules between the exterior solution and the protein cavity. The transfer of $\mathrm{OH}^{-}$into and out of the ferritin interior during battery operation via these channels (reactions (1)-(3)) is an essential property of ferritin that made creation of a bio-nanobattery possible.

4.4. Further Nanobattery Development. Construction of functional nanobatteries has not been extensively reported. Stanish et al. reported [44] a biological battery composed of polymerized vesicles, having benefits of biocompatibility with the potential to assemble on nanopatterned arrays. The maximum operating voltage of this vesicle biobattery was $28.9 \mathrm{mV}$ with a charge capacity of $127 \mathrm{nC}$.

In contrast, the ferritin-based bio-nanobattery is distinct from the vesicle battery. Densely loaded Fe- and Co- or Mnloaded mineral cores were used as half-cells, and electron flow occurred from the mineral phases through the protein shells to current collecting electrodes. The voltage output was 16 times larger, and the coulomb capacity was $\sim 1400$ times larger than the vesicle battery making it a more useful energy storage device. 
The bio-nanobattery system depicted in Figure 1 does not require a membrane if only sufficient ferritin is present to strongly bind to the metal surfaces because the ferritin channels act as ion-permeable membranes, and both electrodes can be in close proximity. Using self-assembling characteristics of ferritins, an array of ferritin units can be assembled into well-organized multilayered ferritins. Figure 6 shows how this approach is applied to increase the capacity of a biobattery by binding multiple layers of ferritins to the electrode surface. The unique ability of electrons to transfer through the intervening protein shells [17] makes possible the stacking of multiple layers of ferritins and still provides for the outermost layer to readily transfer electrons to the metallic electrode.

In this discussion, we have presented two types of battery arrangements and each has advantages and disadvantages. A battery with two half-cells separated by an ion-conducting membrane has a coulombic capacity that depends on the volume and the concentration of the ferritins in the solution. The disadvantage of this arrangement is that remote ferritins must diffuse to the electrode to exchange electrons. While electron exchange readily occurs, diffusion can be a limiting factor in battery function. On the other hand, a battery lacking a membrane has the advantage of being simpler and more responsive because the ferritins are bound directly to the electrode surface, which eliminates diffusion and gives responsive battery performance. Another advantage is that this type of bio-nanobattery can be scaled to the size of a small inscribed gold line. The disadvantage of this arrangement is that such a small size limits the number of bound ferritins, which limits the coulombic capacity of the battery. The stacking of ferritins as proposed in Figure 6 somewhat mitigates this disadvantage. It is likely that both types of bio-nanobatteries will find useful but quite diverse applications.

\section{Acknowledgments}

This research was supported by The National Aeronautics and Space Administration, NASA. Partial support from the Department of Chemistry and Biochemistry and the College of Physical and Mathematical Sciences at the Brigham Young University is gratefully acknowledged. Dr. Richard Frankel's early contribution to the concept of a ferritin bionanobattery was essential to its development.

\section{References}

[1] Y. Shirai, A. J. Osgood, Y. Zhao, K. F. Kelly, and J. M. Tour, "Directional control in thermally driven single-molecule nanocars," Nano Letters, vol. 5, no. 11, pp. 2330-2334, 2005.

[2] H. G. Craighead, "Nanoelectromechanical systems," Science, vol. 290, no. 5496, pp. 1532-1535, 2000.

[3] R. K. Soong, G. D. Bachand, H. P. Neves, A. G. Olkhovets, H. G. Craighead, and C. D. Montemagno, "Powering an inorganic nanodevice with a biomolecular motor," Science, vol. 290, no. 5496, pp. 1555-1558, 2000.

[4] Y. Shirai, A. J. Osgood, Y. Zhao, K. F. Kelly, and J. M. Tour, "Directional control in thermally driven single-molecule nanocars," Nano Letters, vol. 5, no. 11, pp. 2330-2334, 2005.
[5] J. J. Davis, D. A. Morgan, C. L. Wrathmell, D. N. Axford, J. Zhao, and N. Wang, "Molecular bioelectronics," Journal of Materials Chemistry, vol. 15, no. 22, pp. 2160-2174, 2005.

[6] N. Sinha and J. T. W. Yeow, "Carbon nanotubes for biomedical applications," IEEE Transactions on Nanobioscience, vol. 4, no. 2, pp. 180-195, 2005.

[7] S.-H. Chu, J. N. Harb, and S. H. Choi, "Conceptual aspects of nanopower systems," in Proceedings of the 1st World Congress of Biomimetics \& Artificial Muscles, Albuquerque, NM, USA, December 2002.

[8] P. M. Harrison and P. Arosio, "The ferritins: molecular properties, iron storage function and cellular regulation," Biochimica et Biophysica Acta, vol. 1275, no. 3, pp. 161-203, 1996.

[9] P. M. Proulx-Curry and N. D. Chasteen, "Molecular aspects of iron uptake and storage in ferritin," Coordination Chemistry Reviews, vol. 144, pp. 347-368, 1995.

[10] F. Bou-Abdallah, "Iron redox and hydrolysis chemistry of the ferritins," Biochimica et Biophysica Acta, vol. 1800, p. 691, 2010.

[11] B. Webb, J. Frame, Z. Zhao, M. L. Lee, and G. D. Watt, "Molecular entrapment of small molecules within the interior of horse spleen ferritin," Archives of Biochemistry and Biophysics, vol. 309, no. 1, pp. 178-183, 1994.

[12] X. Yang and N. D. Chasteen, "Molecular diffusion into horse spleen ferritin: a nitroxide radical spin probe study," Biophysical Journal, vol. 71, no. 3, pp. 1587-1595, 1996.

[13] D. C. Zapien and M. A. Johnson, "Direct electron transfer of ferritin adsorbed at bare gold electrodes," Journal of Electroanalytical Chemistry, vol. 494, no. 2, pp. 114-120, 2000.

[14] J.-W. Kim, S. Choi, and P. T. Lillehei, "Electrochemically controlled reconstitution of immobilized ferritins for bioelectronics applications," Journal of Electroanalytical Chemistry, vol. 601, no. 8, 2006.

[15] F. Marken, D. Patel, C. E. Madden, R. C. Millward, and S. Fletcher, "The direct electrochemistry of ferritin compared with the direct electrochemistry of nanoparticulate hydrous ferric oxide," New Journal of Chemistry, vol. 26, no. 2, pp. 259263, 2002.

[16] J. E. Frew and H. A. O. Hill, "Direct and indirect electron transfer between electrodes and redox proteins," European Journal of Biochemistry, vol. 172, pp. 261-269, 1988.

[17] B. Zhang, J. N. Harb, R. C. Davis et al., "Electron exchange between $\mathrm{Fe}(\mathrm{II})$-horse spleen ferritin and $\mathrm{Co}(\mathrm{III}) \mathrm{Mn}(\mathrm{III})$ reconstituted horse spleen and Azotobacter vinelandii ferritins," Biochemistry, vol. 45, no. 18, pp. 5766-5774, 2006.

[18] D. L. Jacobs, G. D. Watt, R. B. Frankel, and G. C. Papaefthymiou, "Redox reactions associated with iron release from mammalian ferritin," Biochemistry, vol. 28, no. 4, pp. 1650-1655, 1989.

[19] G. D. Watt, J. W. McDonald, C.-H. Chiu, and K. R. N. Reddy, "Further characterization of the redox and spectroscopicproperties of azotobactervinelandiiferritin," Journal of Inorganic Biochemistry, vol. 51, pp. 745-758, 1993.

[20] G. D. Watt, R. B. Frankel, and G. C. Papaefthymiou, "Reduction of mammalian ferritin," Proceedings of the National Academy of Sciences of the United States of America, vol. 82, no. 11, pp. 3640-3643, 1985.

[21] T. Douglas and V. T. Stark, "Nanophase cobalt oxyhydroxide mineral synthesized within the protein cage of ferritin," Inorganic Chemistry, vol. 39, no. 8, pp. 1828-1830, 2000.

[22] B. Zhang, J. N. Harb, R. C. Davis et al., "Kinetic and thermodynamic characterization of the cobalt and manganese oxyhydroxide cores formed in horse spleen ferritin," Inorganic Chemistry, vol. 44, no. 10, pp. 3738-3745, 2005. 
[23] G. D. Watt, D. Jacobs, and R. B. Frankel, "Redox reactivity of bacterial and mammalian ferritin: is reductant entry into the ferritin interior a necessary step for iron release?" Proceedings of the National Academy of Sciences of the United States of America, vol. 85, no. 20, pp. 7457-7461, 1988.

[24] G. D. Watt, R. B. Frankel, G. C. Papaefthmiou, K. Spartalian, and E. I. Stiefel, "Redox properties and mossbauer spectroscopy of azotobacter vinelandii bacterio ferritin," Biochemistry, vol. 25, p. 4330, 1986.

[25] M. Okuda, K. Iwahori, I. Yamashita, and H. Yoshimura, "Fabrication of nickel and chromium nanoparticles using the protein cage of apoferritin," Biotechnology and Bioengineering, vol. 84, no. 2, pp. 187-194, 2003.

[26] J. W. Kim, S. H. Choi, P. T. Lillehei, S. H. Chu, G. C. King, and G. D. Watt, "Cobalt oxide hollow nanoparticles derived by bio-templating," Chemical Communications, no. 32, pp. 41014103, 2005.

[27] K. K. W. Wong and S. Mann, "Biomemetic synthesis of cadmium sulfide-ferritin nanocomposite," Advanced Materials, vol. 8, pp. 928-932, 1966.

[28] L. Zhang, J. Swift, C. A. Butts, V. Yerubandi, and I. J. Dmochowski, "Structure and activity of apoferritin-stabilized gold nanoparticles," Journal of Inorganic Biochemistry, vol. 101, no. 11-12, pp. 1719-1729, 2007.

[29] F. C. Meldrum, V. J. Wade, D. L. Nimmo, B. R. Heywood, and S. Mann, "Synthesis of inorganic nanophase materials in supramolecular protein cages," Nature, vol. 349, no. 6311, pp. 684-687, 1991.

[30] J. L. Johnson, D. C. Norcross, P. Arosio, R. B. Frankel, and G. D. Watt, "Redox reactivity of animal apoferritins and apoheteropolymers assembled from recombinant heavy and light human chain ferritins," Biochemistry, vol. 38, no. 13, pp. 40894096, 1999.

[31] Y. Ikezoe, Y. Kumashiro, K. Tamada et al., "Growth of giant two-dimensional crystal of protein molecules from a threephase contact line," Langmuir, vol. 24, no. 22, pp. 1283612841, 2008.

[32] T. Matsui, N. Matsukawa, K. Iwahori, K. I. Sano, K. Shiba, and I. Yamashita, "Realizing a two-dimensional ordered array of ferritin molecules directly on a solid surface utilizing carbonaceous material affinity peptides," Langmuir, vol. 23, no. 4, pp. 1615-1618, 2007.

[33] F. Caruso, D. N. Furlong, and P. Kingshott, "Characterization of ferritin adsorption onto gold," Journal of Colloid and Interface Science, vol. 186, no. 1, pp. 129-140, 1997.

[34] C. A. Johnson, Y. Yuan, and A. M. Lenhoff, "Adsorbed layers of ferritin at solid and fluid interfaces studied by atomic force microscopy," Journal of Colloid and Interface Science, vol. 223, no. 2, pp. 261-272, 2000.

[35] E. Casero, M. Darder, K. Takada, H. D. Abruña, F. Pariente, and E. Lorenzo, "Dithiobissuccinimidyl propionate as an anchor for assembling peroxidases at electrodes surfaces and its application in a $\mathrm{H}_{2} \mathrm{O}_{2}$ biosensor," Langmuir, vol. 15, no. 1, pp. 127-134, 1999.

[36] M. Darder, K. Takada, F. Pariente, E. Lorenzo, and H. D. Abrũna, "Addition of sulfhydryl groups to Escherichia coli ribosomes by protein modification with 2-iminothiolane (Methyl 4-Mercaptobutyrimidate)," Analytical Chemistry, vol. 71, no. 24, pp. 5530-5537, 1999.

[37] D. Jacobs, G. D. Watt, R. B. Frankel, and G. C. Papaefthymiou, " $\mathrm{Fe}^{2+}$ binding to Apo and Holo mammalian ferritin," Biochemistry, vol. 28, no. 23, pp. 9216-9221, 1989.

[38] G. D. Watt, R. B. Frankel, D. Jacobs, H. Huang, and G. C. Papaefthymiou, " $\mathrm{Fe}^{2+}$ and phosphate interactions in bacterial ferritin from azotobacter vinelandii," Biochemistry, vol. 31, no. 24, pp. 5672-5679, 1992.

[39] D. Xu, G. D. Watt, J. N. Harb, and R. C. Davis, "Electrical conductivity of ferritin proteins by conductive AFM," Nano Letters, vol. 5, no. 4, pp. 571-577, 2005.

[40] G. C. Ford, P. M. Harrison, D. W. Rice et al., "Ferritin: design and formation of an iron-storage molecule," Philosophical transactions of the Royal Society of London Series B, vol. 304, no. 1121, pp. 551-565, 1984.

[41] Y. Ha, D. Shi, G. W. Small, E. C. Theil, and N. M. Allewell, "Crystal structure of bullfrog M ferritin at $2.8 \AA$ resolution: analysis of subunit interactions and the binuclear metal center," Journal of Biological Inorganic Chemistry, vol. 4, no. 3, pp. 243-256, 1999.

[42] B. Zhang, R. K. Watt, N. Galvez, J. M. Dominguez-Vera, and G. D. Watt, "Rate of iron transfer through the horse spleen ferritin shell determined by the rate of formation of Prussian Blue and Fe-desferrioxamine within the ferritin cavity," Biophysical Chemistry, vol. 120, pp. 96-105, 2006.

[43] X. Liu, W. Jin, and E. C. Theil, "Opening protein pores with chaotropes enhances Fe reduction and chelation of Fe from the ferritin biomineral," Proceedings of the National Academy of Sciences of the United States of America, vol. 100, no. 7, pp. 3653-3658, 2003.

[44] I. Stanish, D. A. Lowy, C.-W. Hung, and A. Singh, "Vesiclebased rechargeable batteries," Advanced Materials, vol. 17, pp. 1194-1198, 2005. 

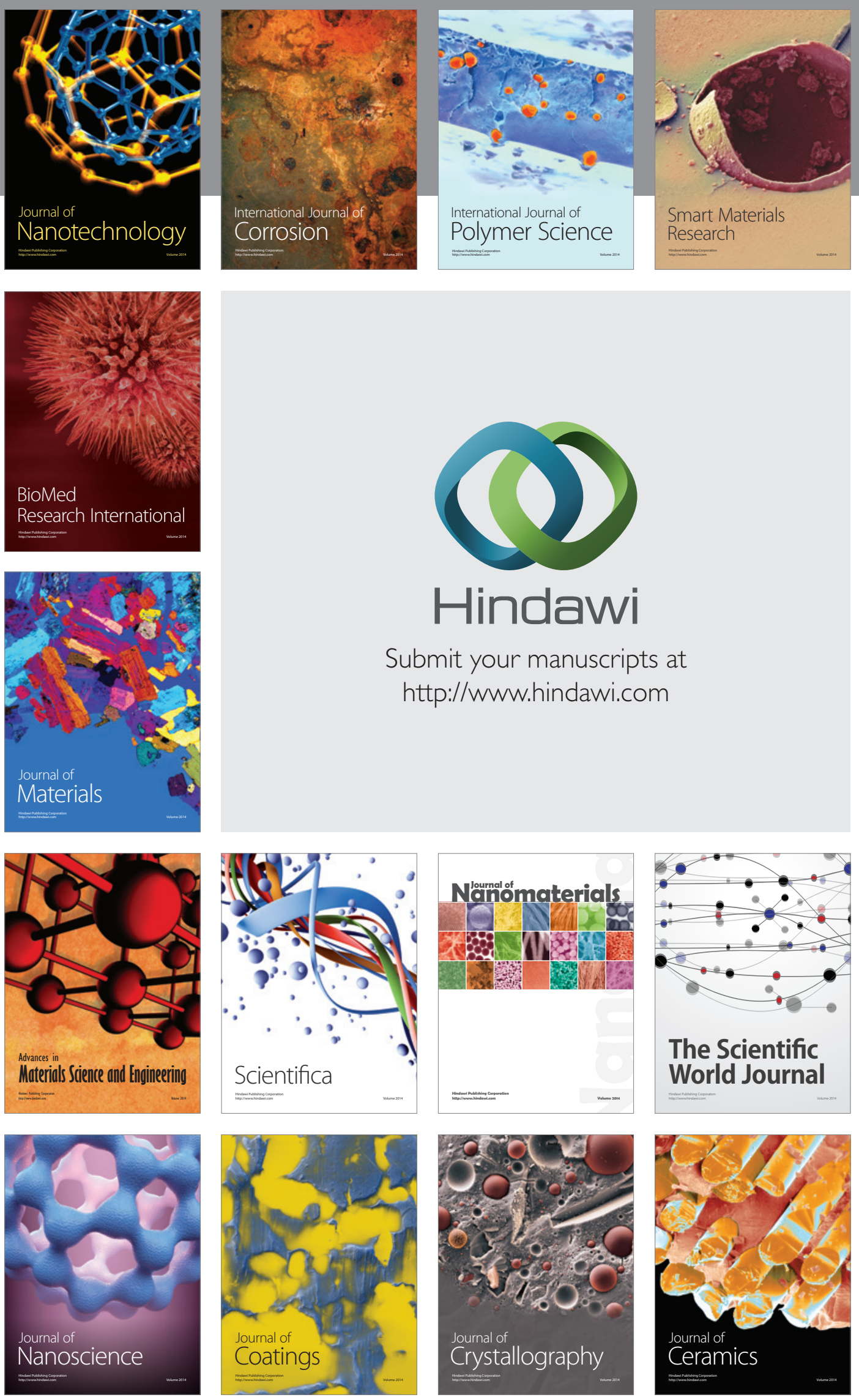

The Scientific World Journal

Submit your manuscripts at

http://www.hindawi.com

\section{World Journal}

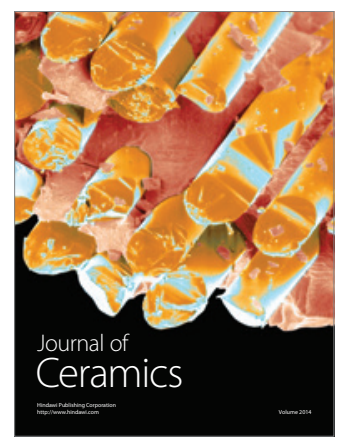

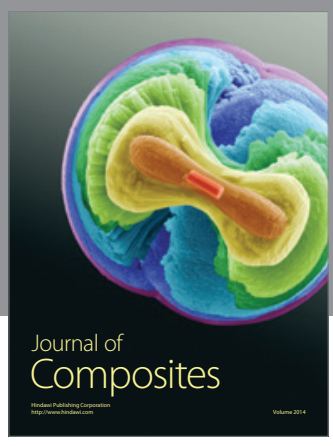
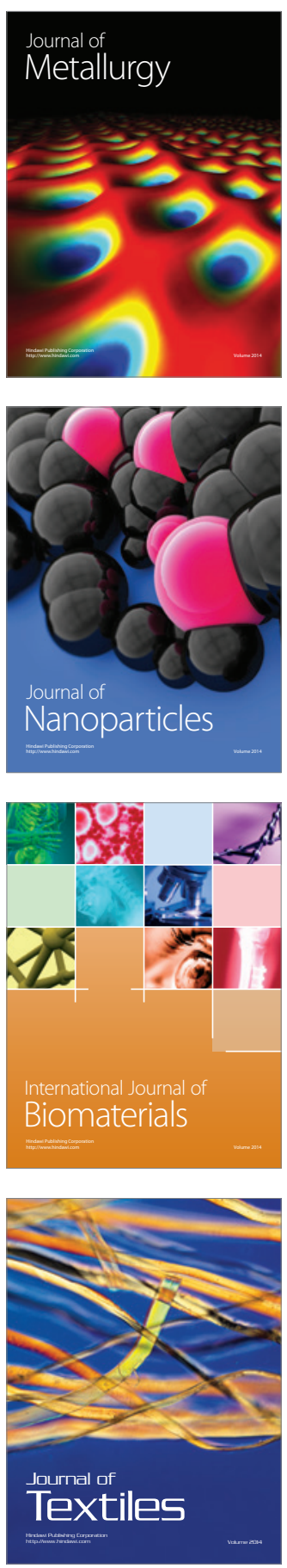